\title{
MUSCLE STRENGTH IN THE OLDEST OLD AND ASSOCIATED FACTORS'
}

\author{
MS. ANDRÉA FERREIRA CARDOSO \\ Programa Floripa Ativa, Secretaria Municipal de Saúde, \\ Prefeitura Municipal de Florianópolis \\ (Florianópolis - Santa Catarina - Brasil) \\ E-mail: deiaacardoso@yahoo.com.br
}

\author{
DRA. ALINE RODRIGUES BARBOSA \\ Departamento de Educação Física, Centro de Desportos, \\ Universidade Federal de Santa Catarina \\ (Florianópolis - Santa Catarina - Brasil) \\ E-mail: aline.r.barbosa@ufsc.br
}

\author{
MS. RAILDO DA SILVA COQUEIRO \\ Departamento de Saúde, Universidade \\ Estadual do Sudoeste da Bahia \\ (Jequié - Bahia - Brasil) \\ E-mail:raiconquista@yahoo.com.br
}

\begin{abstract}
The objective of this cross-sectional household-based study was to investigate the factors associated with muscle strength in the oldest old ( $\geq 80$ years) living in a rural area, of southern Brazil. We interviewed a total of 56 men $(85.0 \pm 4.4 \mathrm{y})$ and 78 women $(84.5 \pm 4.8 \mathrm{y})$. Prevalence of poor performance in the handgrip test (isometric strength) was $39.2 \%$ and was associated with illiteracy, underweight, and cognitive deficit. Poor performance in the "chair stand" test (lower body strength/physical function) was observed in 48.5\% of the elderly and was more prevalent in men and among those who consumed more alcoholic drink/week. The results may be useful as indicators to public health surveillance, and to the development of prevention and intervention actions.
\end{abstract}

KEYWORDS: Aged, 80 and over; Hand Strength; Time and Motion Studies.

I. Financial support: Supported by funding from the Brazilian National Research Council (CNPq - Process 478073/2009-7; Edital Universal). 


\section{INTRODUCTION}

Increased longevity, observed over the past few years (KIRKWOOD, 2008), draws to attention the need to study various aspects related with the health of the very elderly, among which the one that stands out the most is muscular strength, a physiological variable that is fundamental for functional status. Cross-ssectional (BARBOSA et. al., 2005; BARBOSA et al., 201 I ; FREDERIKSEN et al., 2006; LING et al., 20 I0) and longitudinal (FREDERIKSEN et al., 2006; LING et al., 20 I0) data indicate that there is a reduction in muscular strength with the advancing age, and this reduction is different for lower and upper limbs (VALENTINE et al., 2009). In elderly individuals, lowest level of muscular strength can affect the ability to perform daily motor tasks and/or the intensity of such activities (DEN OUDEN et al., 20 I I), resulting in dependence and reduced quality of life.

Studies carried out with elderly from different countries have identified a number of factors positively associated with lower muscular strength: mortality (LING et al., 20 I0), disability (TAEKEMA et al., 20 I 0), reduced cognition (AL SNIH et al., 2009), underweight and/or malnutrition (SAMPER-TERNENT et al., 2008), and morbidities (ARTS et al., 20।0). Furthermore, reduced physical activity levels and lower socio-economic status can contribute to lower muscular strength (KUH et al., 2005).

No studies carried out in Brazil were found to consider the importance of muscular strength in maintaining the functional independence of the oldest old, especially from rural region. Since socio-economic, behavioral and health conditions affecting muscular strength can vary among populations, knowing their determining potentials is fundamental to develop more efficient strategies to prevent and treat functional dependence. Therefore, the objective of this study is to investigate the factors associated with muscle strength in the oldest old living in a rural area, of southern Brazil.

\section{MATERIALS AND METHODS}

\section{AREA OF STUDY}

The city of Antonio Carlos (229 km²), located $30 \mathrm{~km}$ from the capital of the state of Santa Catarina, south region of Brazil, is the highest producer of vegetables of the state. The city has good health and quality of life indicators, presenting high (0.827) Human Development Index (HDI) (PROGRAMA, 2009). Data from the Brazilian census 2010 show that the town's population is composed of 7,458 inhabitants, distributed mostly $(68.6 \%)$ in small rural proprieties. Elderly subjects ( $\geq 60$ years) represent 936 (I2.8\%) of the population in general (INSTITUTO, 20 I I). 
Three Family Health Program teams (one doctor, one nurse, auxiliary nurses and community health) cover the whole town. This program aims to increase population access to primary care (BRANDÃO et al., 20 I I).

\section{STUDY DESIGN AND POPULATION}

This population-based cross-sectional study used part of the baseline data of the epidemiologic survey entitled, "Effectiveness of health actions, physical activity and nutrition in the elderly of Antonio Carlos - SC (Saúde-AC)".

The study population comprises all elderly aged 80 years or older $(n=135)$, registered in the town's Family Health Strategy program. However, one individual was absent during the whole gathering period of data (February to April 20 I 0), resulting in 134 attendees. We used a form-based on the "SABE" survey (Health, well-being and aging) questionnaire (http://hygeia.fsp.usp.br/sabe/Extras/Questionário_2000. pdf) carried out in Brazil and six others Latin America and the Caribbean countries (LEBRÃO; LAURENTI, 2005; ALBALA et al., 2005).

Two trained (60 hours) interviewers collected the data. The precision and accuracy of the physical performance measures were confirmed before the collection of data, with the coordinator's measures considered the gold standard for comparison. The reproducibility of the measures (intraexaminer, 0.93; interexaminer, 0.87) was done in 15 individuals, with a one-week difference between the first and the second measures. The interviewers went to campus accompanied by the Family Health Strategy health agents and authorized by the Board of Health and the town's Social Assistance.

The study was approved by the ethics committee from Universidade Federal de Santa Catarina (protocol no. 189/09).

\section{MUSCULAR STRENGTH}

The testing procedures were the same used in the SABE survey (BARBOSA et al., 2005; BARBOSA et al., 20I I) and will be described brielly.

A handgrip dynamometer (Takey Kiki Kogyio TK I20 I, Japan) was used to assess upper body strength (isometric). The test was taken using the arm that the subject considered dominant, with the elderly in the sitting position. In order to assess the handgrip strength test performance (in kilograms), sex-specific tertiles from the study population were used as cutoff points: $\leq 1^{\text {st }}$ tertile, $27 \mathrm{~kg}$ (men) and $17 \mathrm{~kg}$ (women), poor performance; $>$ Ist tertile $=$ sufficient performance.

The "chair stands" test, used to assess lower body strength/physical function, consisted of time taken in seconds to rise five times from an armless chair (with 
crossed arms) and this test was considered to be successfully accomplished when completed in $<60$ seconds. In order to assess the lower body strength test performance (in seconds), tertiles from the study population were used as cutoff points: $\geq$ I st tertile ( | | seconds), poor performance; < I st tertile = sufficient performance.

Exclusion criteria for the tests: The elderly who refused to take the tests or were unable to understand the instructions due to cognitive problems and subjects unable to perform the maneuvers because of physical limitations; those who could not walk or needed help to keep standing, had paralysis on any extremity, had a prosthesis on either leg, or could not keep balance did not take the chair stand test; those who had undergone arm or hand surgery in the three months prior to data collection did not take a handgrip strength test.

\section{EXPLANATORY VARIABLES}

Sex (women/men); literacy (yes/no); living arrangement (alone/accompanied). The prevalence (yes/no) of previously diagnosed diseases (diabetes mellitus, high blood pressure, arthritis/arthrosis, osteoporosis, stroke, pulmonarydisease or heart attack; number of morbidities (0-2 / 3 or more). Body mass index (BMI $<22.0$ $\mathrm{kg} / \mathrm{m}^{2}$, underweight; BMI $\geq 22.0 \mathrm{~kg} / \mathrm{m}^{2}$, normal range /overweight) (AMERICAN, 2002), body mass and height were measured using standard procedures. In cases when obtaining these measurements was difficult or not possible, equations were used to estimate body mass (CHUMLEA; ROCHE; MUKHERJEE, 1987) and height (CHUMLEA et al., 1988). Consumption of alcoholic drinks (0 or I a week/ 2 or more days a week); smoker (never smoked/current or former smoker); self-reported sitting time (ST), in tertiles ( $<4$ hours/day; $\geq 4<6$ hours/day; $\geq 6$ hours/day) (CRAIG et al., 2003). Cognitive status (cognitive deficit, no cognitive deficit), identified using the Mini Mental Exam, modified and validated (ICAZA; ALBALA, 1999).

\section{STATISTICAL PROCEDURES}

We used mean, standard errors and prevalence rates for the descriptive analysis. The association between dependent variables and explanatory variables were verified by Poisson regression model (crude and adjusted), confidence interval of $95 \%$. In the crude analysis, we used the Wald test to estimate the prevalence of lower levels of handgrip strength and lower limb strength/physical function by categories of explanatory variables. The adjusted analysis followed hierarchical model (FIGURE I) and were included all variables that showed a statistical significance of at least 20\% ( $p \leq 0.20)$ in the crude analysis. 
The variables of level I were adjusted for themselves, and those that obtained $p \leq 0.20$ remained in the model for adjustment of the variables in the next levels. Subsequently, we included variables in the level 2 ( $p \leq 0.20$ in the crude analysis). The variables that remained statistically significant at least $20 \%$ were retained in models, along with the variables in level 1 , to make the adjustment variables in level 3 ( $p$ value $\leq 0.20$ in the crude analysis). In this step, variables that remained a statistical significance of at least $20 \%$ were maintained in the final models, together with levels I and 2 variables. The significance level adopted was 5\% ( $\leq \leq 0.05)$. The data was computed and assessed with Statistical Package for the Social Sciences for Windows (SPSS, version 16.0 ${ }^{\circledR}$ ).

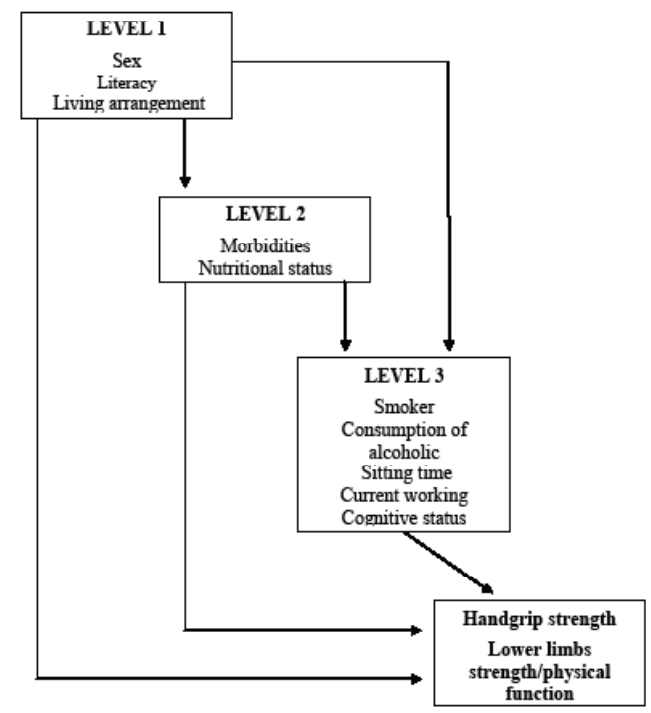

Figure I. Simplified hierarchy model for handgrip strength and lower limb strength/physical function in oldest old. (Antonio Carlos-SC, Brazil, 2010)

\section{RESULTS}

Among participants, $58.2 \%$ were women $(n=78)$ and $41.8 \%$ were men $(n=56)$. The mean age was $85.0 \pm 4.4$ (male) and $84.5 \pm 4.8$ (female). There was one refusal to perform the tests, two of the elderly attempted but did not accomplish the lower limbs strength test, three individuals were incapable of performing the handgrip test and 21 (twenty one) were incapable of performing the lower limb strength/physical function test. 
The characteristics of the study population are presented in Table I. It can be observed that the most of elderly was literate, lived accompanied, reported 0-2 morbidities, never smoker, consumed alcohol 2 or + day/week, had normal range/overweight, had no cognitive deficit, and was not currently working. The most frequent diseases were (in order of prevalence): high blood pressure, cardiac disease and arthritis/arthrosis. Prevalence of the most sitting time ( $\geq 6$ h./day ) was approximately one third.

Table I. Characteristics of the study population (Antonio Carlos-SC, Brazil, 20 I0)

\begin{tabular}{|c|c|c|c|}
\hline Variables & Response rate (\%) & $n$ & $\%$ \\
\hline Literacy & 100.0 & & \\
\hline No & & 23 & 17.2 \\
\hline Yes & & || $\mid$ & 82.8 \\
\hline Living arrangement & 100.0 & & \\
\hline Alone & & 23 & 17.2 \\
\hline Accompanied & & 111 & 82.8 \\
\hline Hypertension & 100.0 & & \\
\hline Yes & & 98 & 73.1 \\
\hline No & & 36 & 26.9 \\
\hline Diabetes & 99.3 & & \\
\hline Yes & & 22 & 16.5 \\
\hline No & & 111 & 83.5 \\
\hline Arthritis/Arthrosis & 99.3 & & \\
\hline Yes & & 30 & 22.6 \\
\hline No & & 103 & 77.4 \\
\hline Osteoporosis & 97.8 & & \\
\hline Yes & & 25 & 19.1 \\
\hline No & & 106 & 80.9 \\
\hline Heart attack & 99.3 & & \\
\hline Yes & & 43 & 32.3 \\
\hline No & & 90 & 67.7 \\
\hline Pulmonary disease & 100.0 & & \\
\hline Yes & & 17 & 12.7 \\
\hline No & & 117 & 87.3 \\
\hline Stroke & 100.0 & & \\
\hline Yes & & 13 & 9.7 \\
\hline No & & 121 & 90.3 \\
\hline Number of morbidities & 100.0 & & \\
\hline 3 or more & & 49 & 36.6 \\
\hline $0-2$ & & 85 & 63.4 \\
\hline
\end{tabular}




\begin{tabular}{|c|c|c|c|}
\hline Variables & Response rate (\%) & $n$ & $\%$ \\
\hline Nutritional status & 99.3 & & \\
\hline Underweight & & 25 & 18.8 \\
\hline Normal range/overweight & & 108 & 81.2 \\
\hline Smoker & 100.0 & & \\
\hline Current/ex-smoker & & 42 & 31.3 \\
\hline Never & & 92 & 68.7 \\
\hline Alcohol consumption & 100.0 & & \\
\hline 0-I day/week & & 12 & 9.0 \\
\hline 2 or + day/week & & 122 & 91.0 \\
\hline Sitting time & 92.5 & & \\
\hline$<4$ h./day & & 42 & 33.9 \\
\hline$\geq 4$ h. and $<6$ h/day & & 45 & 36.3 \\
\hline$\geq 6$ h./day & & 37 & 29.8 \\
\hline Current working & 100.0 & & \\
\hline No & & 112 & 83.6 \\
\hline Yes & & 22 & 16.4 \\
\hline Cognitive status & 100.0 & & \\
\hline Cognitive deficit & & 36 & 26.9 \\
\hline No cognitive deficit & & 98 & 73.1 \\
\hline
\end{tabular}

"The bedridden and non-wandering elderly $(n=10)$ were excluded.

\section{HANDGRIP STRENGTH AND ASSOCIATED FACTORS}

Handgrip values varied from 2 to $30 \mathrm{~kg}(19.0 \pm 5.5 \mathrm{~kg})$, for women $(\mathrm{n}=76)$ and from I 2 to $4 \mathrm{I} \mathrm{kg}(30.0 \pm 7.2 \mathrm{~kg})$ for men $(n=54)(p<0.00 \mathrm{I})$. The prevalence of poor performance in this test was $39.2 \%$.

Poor performance in the handgrip strength test was more prevalent between elderly who were illiterate (not know how to read or write) $(p=0.038)$, with underweight $(p=0.008)$, and with cognitive deficit $(p<0.00 \mathrm{I})$. There were no statistical differences in relation to any other investigated variables. The results of the crude analysis showed that variables (explanatory) know how to read and write, living arrangement, pulmonary disease, nutritional status, sitting time and cognitive status reach statistical significance $(p \leq 0,20)$ to be included in the hierarchical model (TABLE 2). 
Table 2. Prevalence, crude prevalence ratios (PR) and confidence intervals (Cl 95\%) of poor performance in the handgrip test, according explanatory variables. (Antonio Carlos-SC, Brazil, 20 I0)

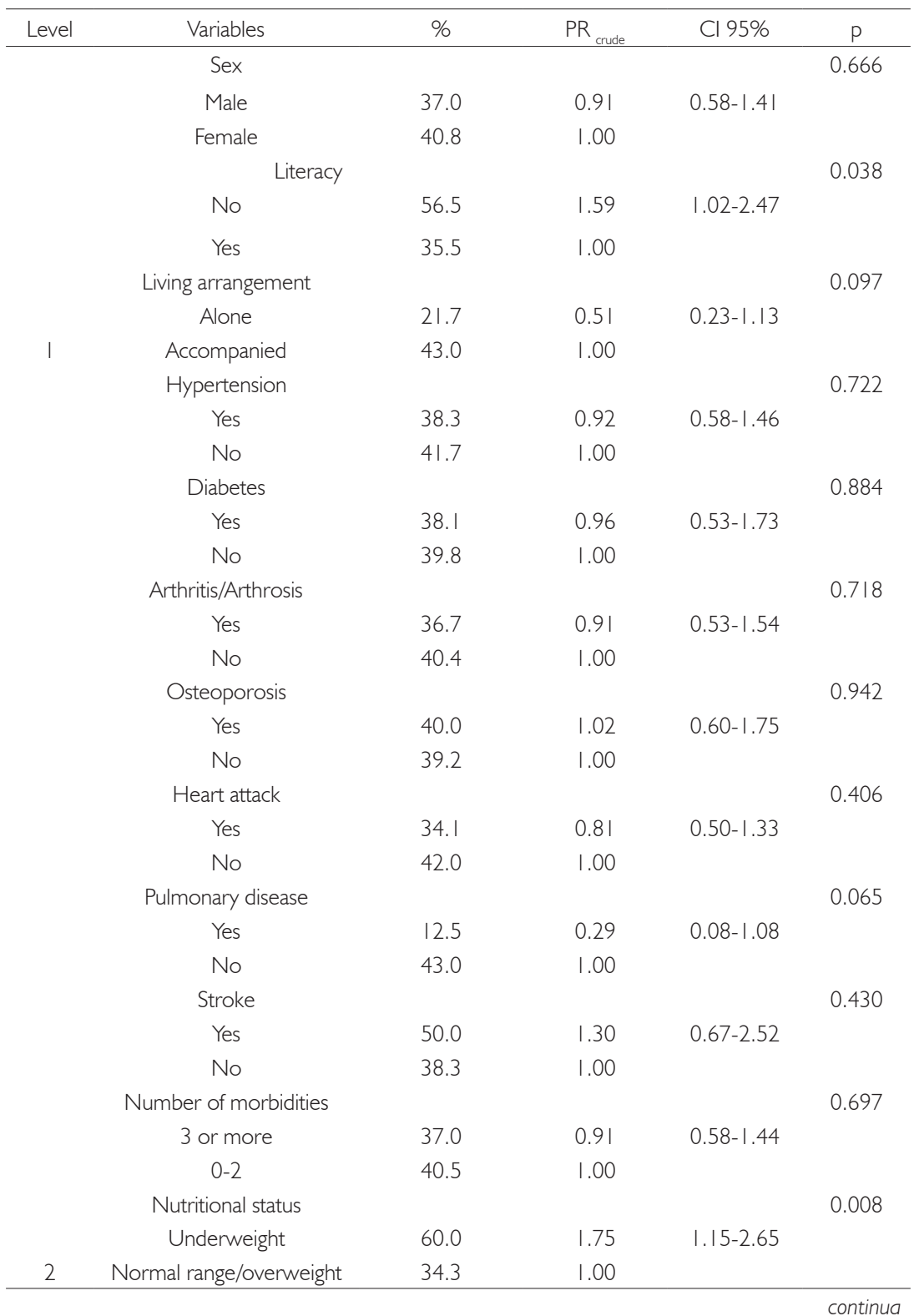




\begin{tabular}{|c|c|c|c|c|c|}
\hline Level & Variables & $\%$ & $P R_{\text {crude }}$ & Cl $95 \%$ & $p$ \\
\hline & Smoker & & & & 0.789 \\
\hline & Current/ex-smoker & 37.5 & 0.94 & $0.58-1.50$ & \\
\hline & Never & 40.0 & 1.00 & & \\
\hline & Alcohol consumption & & & & 0.385 \\
\hline & 2 or + day/week & 50.0 & |.31 & $0.7|-2.4|$ & \\
\hline & 0-I day/week & 38.1 & 1.00 & & \\
\hline & Sitting time & & & & 0.090 \\
\hline & $\geq 6$ h./day & 50.0 & 1.54 & $0.88-2.68$ & \\
\hline & $\geq 4$ h. and $<6$ h/day & 28.9 & 0.89 & $0.46-1.7 \mid$ & \\
\hline & $<4$ h./day & 32.4 & 1.00 & & \\
\hline & Current working & & & & 0.767 \\
\hline & No & 39.8 & 1.09 & $0.60-1.99$ & \\
\hline & Yes & 36.4 & 1.00 & & \\
\hline & Cognitive status & & & & $<0.001$ \\
\hline & Cognitive deficit & 66.7 & 2.23 & $\mid .51-3.29$ & \\
\hline 3 & No cognitive deficit & 29.9 & 1.00 & & \\
\hline
\end{tabular}

Table 3 presents the adjusted analysis (multiple Poisson model) for poor performance in the handgrip strength test. After intra-block and inter-block adjustments (hierarchical model), the variable sitting time did not reach the significance criterion ( $p \leq 0.20)$. Poor performance in the handgrip strength test remained positively associated with illiterate, underweight, and cognitive deficit. There was no associations between poor handgrip strength and variables living arrangement and pulmonary disease.

Table 3. Adjusted prevalence ratios (PR) and confidence intervals (Cl 95\%) for poor performance in the handgrip test, according hierarchical analysis model. (Antonio Carlos-SC, Brazil, 2010)

\begin{tabular}{|c|c|c|c|c|}
\hline Level & Variables & $P R_{\text {adjusted }}$ & IC 95\% & $\mathrm{p}$ \\
\hline & Literacy & & & 0.041 \\
\hline & No & 1.55 & $1.02-2.35$ & \\
\hline & Yes & 1.00 & & \\
\hline & Living arrangement & & & 0.118 \\
\hline & Alone & 0.52 & $0.23-1.18$ & \\
\hline \multirow[t]{6}{*}{ । } & Accompanied & 1.00 & & \\
\hline & Pulmonary disease & & & 0.078 \\
\hline & Yes & 0.30 & $0.08-1.15$ & \\
\hline & No & 1.00 & & \\
\hline & Nutritional status & & & 0.020 \\
\hline & Underweight & 1.57 & $1.07-2.29$ & \\
\hline 2 & Normal range/overweight & 1.00 & & \\
\hline
\end{tabular}




\begin{tabular}{ccccc}
\hline Level & Variables & PR & IC 95\% & P \\
\hline & Cognitive status & & & 0.005 \\
& Cognitive deficit & 1.80 & $1.20-2.7 \mid$ & \\
3 & No cognitive deficit & 1.00 & & \\
\hline
\end{tabular}

\section{LOWER LIMB STRENGTH/PHYSICAL FUNCTION AND ASSOCIATED FACTORS}

The mean value in the lower limb strength/physical function test was $15.0 \pm$ 5.7 seconds ( 7 to 32 seconds) for females $(n=52$ ), and $13.0 \pm 4.6$ seconds ( 6 to 30 seconds) for males $(n=45)(p<0.01)$. The prevalence of poor performance in this test was $48.5 \%$.

The data in Table 4 shows the prevalence and results of the crude analysis of poor performance in the test (lower limb strength/physical function), according explanatory variables. Poor performance in the lower limb strength/ physical function test was more prevalent in the male $(p=0.014)$, among individuals who reported more frequent consumption of alcoholic drinks $(p=0.012)$ and those who reported spending less sitting time $(p=0.043)$. There were no significant differences in relation to the other investigated variables.

Table 4. Prevalence, crude prevalence ratios (PR) and confidence intervals (Cl 95\%) of poor performance in the lower limb strength/physical function test, according explanatory variables. (Antonio Carlos-SC, Brazil, 20 I0)

\begin{tabular}{|c|c|c|c|c|c|}
\hline Level & Variables & $\%$ & PR crude & Cl 95\% & $\mathrm{P}$ \\
\hline & Sex & & & & 0.014 \\
\hline & Male & 62.2 & 1.70 & $1.11-2.60$ & \\
\hline & Female & 36.5 & 1.00 & & \\
\hline & Literacy & & & & 0.138 \\
\hline & No & 29.4 & 0.56 & $0.26-1.20$ & \\
\hline & Yes & 52.5 & 1.00 & & \\
\hline & Living arrangement & & & & \\
\hline & Alone & 40.0 & 0.79 & $0.44-|.4|$ & 0.425 \\
\hline । & Accompanied & 50.6 & 1.00 & & \\
\hline
\end{tabular}




\begin{tabular}{|c|c|c|c|c|c|}
\hline Level & Variables & $\%$ & $P R_{\text {crude }}$ & Cl 95\% & $\mathrm{p}$ \\
\hline & Hypertension & & & & 0.632 \\
\hline & Yes & 50.0 & 1.12 & $0.69-1.82$ & \\
\hline & No & 44.4 & 1.00 & & \\
\hline & Diabetes & & & & 0.451 \\
\hline & Yes & 58.3 & 1.22 & $0.72-2.08$ & \\
\hline & No & 47.6 & 1.00 & & \\
\hline & Arthritis/Arthrosis & & & & 0.958 \\
\hline & Yes & 47.4 & 0.99 & $0.58-1.67$ & \\
\hline & No & 48.1 & 1.00 & & \\
\hline & Osteoporosis & & & & 0.505 \\
\hline & Yes & 41.2 & 0.81 & $0.44-1.49$ & \\
\hline & No & 50.6 & 1.00 & & \\
\hline & Heart attack & & & & 0.781 \\
\hline & Yes & 50.0 & 1.06 & $0.68-1.65$ & \\
\hline & No & 47.0 & 1.00 & & \\
\hline & Pulmonary disease & & & & 0.899 \\
\hline & Yes & 50.0 & 1.04 & $0.59-1.83$ & \\
\hline & No & 48.2 & 1.00 & & \\
\hline & Stroke & & & & 0.502 \\
\hline & Yes & 33.3 & 0.67 & $0.21-2.13$ & \\
\hline & No & 49.5 & 1.00 & & \\
\hline & Number of morbidities & & & & 0.526 \\
\hline & 3 or more & 43.8 & 0.86 & $0.54-1.36$ & \\
\hline & 0- 2 & 50.8 & 1.00 & & \\
\hline & Nutritional status & & & & 0.673 \\
\hline & Underweight & 52.9 & I.II & $0.67-1.84$ & \\
\hline \multirow[t]{16}{*}{2} & Normal range/overweight & 47.5 & 1.00 & & \\
\hline & Smoker & & & & 0.074 \\
\hline & Current/ex-smoker & 60.6 & 1.44 & $0.96-2.14$ & \\
\hline & Never & 42.2 & 1.00 & & \\
\hline & Alcohol consumption & & & & 0.012 \\
\hline & 2 or + day/week & 75.0 & 1.68 & $|| 2-2.5 \mid$. & \\
\hline & 0-I day/week & 44.7 & 1.00 & & \\
\hline & Sitting time & & & & 0.043 \\
\hline & $\geq 6$ h./day & 46.2 & 0.71 & $0.44-1.16$ & \\
\hline & $\geq 4$ h. and $<6$ h/day & 35.1 & 0.54 & $0.33-0.90$ & \\
\hline & $<4$ h./day & 64.7 & 1.00 & & \\
\hline & Current working & & & & 0.676 \\
\hline & No & 47.4 & 0.90 & $0.56-1.45$ & \\
\hline & Yes & 52.4 & 1.00 & & \\
\hline & Cognitive status & & & & 0.281 \\
\hline & Cognitive deficit & 35.3 & 0.69 & $0.35-1.36$ & \\
\hline 3 & No cognitive deficit & 51.3 & 1.00 & & \\
\hline
\end{tabular}


Crude analysis results showed that variables sex, literacy, smoker, consumption of alcohol, sitting time and cognitive status reached statistical significance $(p \leq 0.20)$ to be included in the multiple hierarchical model.

Table 5 presents the adjusted analysis (multiple Poisson model) poor performance in the lower limb strength/physical function test. After intra-block and inter-block adjustments, variables smoker and cognitive status did not remain in the model as they did not complying with the significance criterion $(p \leq 0.20)$. The final model showed that poor performance in the lower limb strength/physical function test was associated with the male sex and with higher consumption of alcoholic drinks ( 2 or + day/week). No associations were verified between poor performance in this test and variable sitting time.

Table 5. Adjusted prevalence ratios (PR) and confidence intervals (Cl 95\%) for poor performance in the lower limb strength/physical function test, according hierarchical analysis model. (Antonio Carlos-SC, Brazil, 20 I0)

\begin{tabular}{|c|c|c|c|c|}
\hline Level & Variables & $P R_{\text {adjusted }}$ & Cl 95\% & $p$ \\
\hline & Sex & & & 0.005 \\
\hline & Male & 1.83 & ।.20-2.79 & \\
\hline & Female & 1.00 & & \\
\hline & Literacy & & & 0.078 \\
\hline & no & 0.49 & $0.22-1.08$ & \\
\hline \multirow[t]{7}{*}{ । } & Yes & 1.00 & & \\
\hline & Alcohol consumption & & & 0.044 \\
\hline & 2 or + day/week & 1.52 & $1.01-2.29$ & \\
\hline & 0-I day/week & 1.00 & & \\
\hline & Sitting time & & & 0.068 \\
\hline & $\geq 6$ h./day & 0.78 & $0.50-1.22$ & \\
\hline & $\geq 4$ h. and $<6$ h/day & 0.56 & $0.35-0.92$ & \\
\hline 3 & $<4$ h./day & 1.00 & & \\
\hline
\end{tabular}

\section{DISCUSSION}

According the comprehensive literature search (Scielo and Medline), this is the first study carried out in Brazil that analyzes the association between muscular strength and socio-demographic factors, health conditions and lifestyle of oldest old subjects in a rural community in Southern Brazil. The results showed that poor performance in the handgrip strength test was positively associated with cognitive 
deficit, illiterate and underweight, independent from the other variables. The poor performance in the lower limb strength/physical function test was positively associated with male sex and higher consumption of alcoholic drinks.

By analyzing handgrip strength in a survey that used the same methodology and instrument of the present study, it has been possible to verify that the values displayed by the men and women of Antônio Carlos were higher than those observed in the elderly (aged 80 and over) of São Paulo/Brazil (BARBOSA et al. et al., 2005). The differences in handgrip strength values probably reflect the activities and socio-environmental differences along the lifetime of the elderly. Antônio Carlos is a rural city and most elderly of the present study have worked in agriculture throughout the life, while in Sao Paulo, the biggest city of Brazil, it probably did not happened.

It's not clear how cognitive deficit might be associated with handgrip strength (AL SNIH et al., 2009; BOYLE et al., 2009). However, Raji et al. (2005) in a prospective study showed that the elderly who displayed "poor" (initial) cognitive status had a more significant decrease in handgrip strength than those with good cognition, independent from other demographic and health factors. Furthermore, loss of muscle strength can result of an underlying disease process that also leads to cognitive decline (BOYLE et al., 2009). The association between poor performance in the handgrip strength test and illiterate, observed in the present study, can be explained by the fact that individuals with more schooling have higher incomes, better access to health services, better health-related quality of life (LOUVISON et al., 2008), and thus, higher muscular strength.

The results showed that underweight was associated with a poor handgrip strength, as verified in other studies (BARBOSA et al., 2006; PIETERSE; MANANDHAR; ISMAIL, 2002). In oldest old subjects, underweight can be attributed to reduced muscle mass and body fat. Muscle mass is not the only factor responsible for muscular strength but its reduction affects (negatively) the muscular strength (THOMAS, 2007). The mean values of handgrip strength (kg) were higher for men than for women as observed in other studies. (BARBOSA et al., 2005; BARBOSA et al., 20 I l; PIETERSE; MANANDHAR; ISMAIL, 2002). We believe that the lack of association between handgrip strength and sex occurred because the categorization used in this test (different values for men and for women).

The differences between men and women in relation to physical capacity and specifically to muscular strength are well known. Hormonal differences, especially higher levels of testosterone and higher muscle mass observed in men, as well as higher levels of body fat in women, explain this difference (VALENTINE et al., 2009) in favor of men. Although men present a more pronounced reduction in muscular function with the advancement of age, in absolute terms this function is better than in women of all ages (DITROILO et al., 20I0). 
The results of the present study have shown that men showed lower mean values (time in seconds) than women in the lower limbs strength/physical function test, as observed in other studies (BARBOSA et al., 2005; BARBOSA et al., 20 I I). However, poor performance in this test was associated with the male sex. This test is influenced by many psychological processes (as well as sensorimotor processes), such as anxiety, disposition, sensation of pain and depression (LORD et al., 2002). Thus, it is possible women be more receptive to perform the test than men. However, these variables were not assessed in the present study.

The final model showed that the consumption of alcohol twice or more in a week was associated to poor performance in the lower limbs strength/physical function test. The benefits and problems associated with the consumption of alcohol among the elderly are controversial. Some studies point out to benefits from light consumption regarding mortality (COSTANZO et al., 20 I 0), diminished dementia (SOLFRIZZI et al., 2007), multiple cardiovascular events (RONKSLEY et al., 20 I I), motor performance and functional capacity (CAWTHON et al., 2007). Disorders arising from excessive alcohol consumption among the elderly are common and is associated with a number of health problems, such as a higher number of falls, mental confusion, depression (O'CONNELL et al., 2003) and poor performance in motor tasks (CAWTHON et al., 2007). Additionally, the alcohol consumption can be associated with the use of medicinal drugs and the presence of co-morbidities.

The study carried out with 5962 men (aged 65 and over), showed that the association between alcohol consumption and motor performance displays a $U$ curve, that is, both nondrinkers and individuals with high levels of alcohol consumption had a worse performance in physical tests, including the "sitting down and getting up" test (CAWTON et al., 2007). The authors used the CAGE (EWING, 1984) questionnaire to identify people with drinking problems who should respond to questions about quantities ingested per week and per year, and classifying them in 6 categories (nondrinkers, intermittent use, low consumption, moderate-low consumption, moderate-high consumption, and excessive consumption).

The present study did not determine how many glasses of alcoholic beverage the individuals had per day, but how many days a week they had a drink, which can be a limitation of the study and can make it difficult to compare it with the study by Cawton et al. (2007). Other differences, such as the age of the elderly, as well as their health conditions and lifestyle, make it difficult to compare both studies.

The factors associated with poor performance in the handgrip strength test and lower limb strength/physical function test were different. This difference may be due to the characteristics of the tests. Although both are considered to be objective measurements, the first test verifies isometric strength (kilograms), 
whereas the lower limb strength/physical function test is seen as an indicator or a close measure of the strength of lower limbs (RIKLI, JONES I999; LORD et al., 2002). Furthermore, along their lifetime, decrease in muscular strength seems to be enhanced in the lower limbs (DITROILO et al., 20 I0), due also to differences in movement patterns. Also, while the upper limbs are innervated only through the brachial plexus, the lower limbs are innervated via the lumbar plexus and the sacral plexus, involving a larger quantity of muscles. This can generate greater difficulty of contraction between muscles, muscle shortening, and also contribute to increasing muscle weakness (THOMAS, 2007).

No association between motor performance and the presence of diseases were observed in this study, as evidenced by other authors (LOUIE; WARD, 20 I 0; CASTANEDA-SCEPPA et al., 2010). However, it is important to highlight that diseases/pathologies can lead to functional limitation and consequent disability (RIKLI; JONES, 1999).

Finally, we should recognize some limitations and strengths points of the present study. Strengths include the total population of oldest old of Antônio Carlos, involve elderly from a rural area, and the use of the questionnaire and tests previously utilized in national (BARBOSA et al., 2005; BARBOSA et al., 2006; LEBRÃO, LAURENTI, 2005) and international (ALBALA et al., 2005; BARBOSA et al., 20 I I) studies. The cross-sectional design precludes making any causal inferences between poor performance in the tests and explanatory variables. Other of the possible limitations of this study was the use of self-reported information concerning the occurrence of morbidities and sitting time. However, it is import to note that data collection occurred with the assistance of health community agents, which knew all the oldest old, and confirmed the presence of morbidities.

\section{CONCLUSIONS}

The results obtained in the present study allow us to conclude that impaired cognitive status, not knowing how to read or write and underweight are independently associated with poor performance in the handgrip strength test. The male sex and consumption of alcoholic beverages twice or more a week are associated with poor performance in the lower limb strength test. Although the results identify an association between poor performance in the tests and these variables, they do not establish a cause and effect relationship. We presented the results to health professionals of Antônio Carlos, and we expect that the data are useful as indicators to public health surveillance, and to the development of prevention and intervention actions. Furthermore, the data could be used as reference for elderly from municipalities with similar characteristics. 


\section{Força muscular e fatores associados em idosos longevos}

RESUMO: O objetivo deste estudo transversal de base populacional e domiciliar foi avaliar os fatores associados à força muscular em idosos longevos ( $\geq 80$ anos), residentes em área rural, no sul do Brasil. Foram entrevistados 56 homens (85,0 \pm 4,4 anos) e 78 mulheres (84,5 $\pm 4,8$ anos. A prevalência de desempenho fraco no teste de força de preensão manual (foi 39,2\%, sendo associado ao analfabetismo, baixo peso e déficit cognitivo. O desempenho fraco no teste "sentar e levantar" (força de membros inferiores/função física) foi observado em $48,5 \%$ dos idosos, sendo mais prevalente entre os homens e entre os que consumiam mais bebidas alcoólicas. Os resultados poderão ser usados como indicadores para vigilância em saúde e no desenvolvimento de ações de intervenção e prevenção.

PALAVRAS-CHAVE: Idoso de 80 anos ou mais; força da mão; estudos de tempo e movimento.

\section{Fuerza muscular y factores asociados en ancianos muy viejos}

RESUMO: El objetivo de este estudio transversal de base poblacional y domiciliar fue evaluar los factores asociados a la fuerza muscular en ancianos muy viejos ( $\geq 80$ anos) residentes en área rural, en el sur de Brasil. Fueron entrevistados 56 hombres (85,0 44,4 años) y 78 mujeres $(84,5 \pm 4,8$ años). La frecuencia de desempeño débil en la prueba de fuerza de la mano fue $39,2 \%$, siendo asociada al analfabetismo, bajo peso y déficit cognitivo. El desempeño débil en la prueba "sentar y levantar" (fuerza de miembros inferiores/función física) fue observado en 48,5\% de los ancianos, siendo más prevalente entre los hombres y entre los que consumían más bebidas alcohólicas. Los resultados podrán ser usados como indicadores para vigilancia en salud y en el desarrollo de acciones de intervención y prevención.

PALABRAS CLAVE: Anciano de 80 o más años; fuerza de la mano; estudios de tiempo y movimiento.

\section{REFERENCES}

ALBALA, C. et al. Encuesta Salud, Bienestar y Envejecimiento (SABE): metodología de la encuesta y perfil de la población estudiada. Revista Panamericana de Salud Pública, Washington, v. 17, n. 5/6, p. 307-22, jun. 2005.

AL SNIH, S. et al. Frailty and incidence of activities of daily living disability among older Mexican Americans. Journal of Rehabilitation Medicine, Uppsala, v. 4I, n. II, p. 892-897, nov. 2009.

AMERICAN ACADEMY OF FAMILY PHYSICIANS. AMERICAN DIETETIC ASSOCIATION; NATIONAL COUNCIL ON THE AGING. Nutrition screening e intervention resources for healthcare professionals working with older adults. Washington, 2002. Disponível em: <http://www. eatright.org/cps/rde/xchg/ada/hs.xsl/nutrition_nsi_ENU_HTML.htm>. Acesso em: 2 I jul. 2008.

ARTS, I. E. et al. Vascular status and physical functioning: the association between vascular status and physical functioning in middle-aged and elderly men: a cross-sectional study. European Journal of Preventive Cardiology, Sophia Antipolis, v. 17, n. 2, p. 21 I-6, apr. 2010.

BARBOSA, A. R. et al. Functional limitations of Brazilian elderly by age and gender differences: data from SABE. Cadernos de Saúde Pública, Rio de Janeiro, v. 2 I , n. 4, p. I I 77- I 785, jul/ago. 2005. 
BARBOSA, A. R. et al. Relação entre estado nutricional e força de preensão manual em idosos do Município de São Paulo, Brasil: dados da Pesquisa SABE. Revista Brasileira de Cineantropometria e Desempenho Humano, Florianópolis, v. 8, n. I, p. 37-44, abr. 2006.

BARBOSA, A. R. et al. Age and gender differences regarding physical performance in the elderly from Barbados and Cuba. Revista de Salud Pública, Bogotá, v. 13, n. I, p. 54-66, feb. 201 I.

BRANDÃO, J. R. M. et al. The family health system: analysis of a health survey in São Paulo, Brazil. Journal of Epidemiology \& Community Health, London, v. 65, n. 6, p. 483-490, jun. 201 I .

BOYLE, P.A. et al. Association of muscle strength with the risk of Alzheimer Disease and the rate of cognitive decline in community-dwelling older persons. Archives of Neurology, New York, v. 66, n. II, p.1339-1344, nov. 2009.

CASTANEDA-SCEPPA, C. et al. Physical function and health status in aging puerto rican adults: the Boston puerto rican health study. Journal of Aging and Health, Newbury Park, v. 22, n. 5, p. 653-672, aug. 2010.

CAWTHON, P. M. et al. Alcohol use, physical performance, and functional limitations in older men. Journal of the American Geriatrics Society, Malden, v. 55, n. 2, p. 21 2-220, feb. 2007.

CHUMLEA, W. C. et al. Prediction of body weight for the nonambulatory elderly from anthropometry. Journal of the American Dietetic Association, Chicago, v. 88, n. 5, p. 564-568, may 1988.

CHUMLEA, W. C.; ROCHE, A. F.; MUKHERJEE, D. Nutritional assessment of the elderly through anthropometry. Washington: Wright State University School of Medicine, 1987.

COSTANZO, S. et al. Alcohol consumption and mortality in patients with cardiovascular disease: a meta-analysis. Journal of the American College Cardiology, San Diego, v. 55, n. I3, p. 1339-1347, mar. 2010.

CRAIG, C. L. et al. International Physical Activity Questionnaire: I2-country reliability and validity. Medicine \& Science in Sport \& Exercise, Indianapolis, v. 35, n. 8, p. I 38 I - I 395, aug. 2003.

DEN OUDEN, M. E. et al. Physical performance characteristics related to disability in older persons: a systematic review. Maturitas, Oxford, v. 69, n. 3, p. 208-219, jul. 201 I.

DITROILO, M. et al. Effects of age and limb dominance on upper and lower limb muscle function in healthy males and females aged 40-80 years. Journal of Sports Sciences, Walsall, v. 28, n. 6, p. 667-677, apr. 2010.

EWING, J. A. Detecting alcoholism: the CAGE questionnaire. The Journal of the American Medical Association, Chicago, v. 252, n. 14, p. 1905-1907, oct. 1984.

FREDERIKSEN, H. et al. Age trajectories of grip strength: cross-sectional and longitudinal data among 8342 danes aged 46 to 102. Annals of Epidemiology, Philadelphia, v. 16, n. 7 , p. 554-562, jan. 2006. 
ICAZA, M. C.; ALBALA, C. Projeto SABE. Minimental State Examination (MMSE) del estudio de dementia em Chile: análisis estatístico. Washington: Organización Panamericana de La Salud, 1999.

INSTITUTO BRASILEIRO DE GEOGRAFIA E ESTATÍ́STICA (IBGE). Indicadores sociodemográficos e de saúde no Brasil 2009. Brasília, 25 maio 20 I I. Disponível em: < http://www. ibge.gov.br>. Acesso em: 25 maio 201 I.

KIRKWOOD, T. B. L. A systematic look at an old problem: as life expectancy increases, a systems-biology approach is needed to ensure that we have a healthy old age. Nature, London, v. 45I, n. 7179, p. 644-647, feb. 2008.

$\mathrm{KUH}$, D. et al. Grip strength, postural control, and functional leg power in a representative cohort of British men and women: associations with physical activity, health status, and socioeconomic conditions. The Journal of Gerontology, Serie A: biological sciences medical sciences, Oxford, v. 60, n. 2, p. 224-231, feb. 2005.

LEBRÃO, M. L.; LAURENTI, R. Health, well-being and aging: the SABE study in São Paulo, Brazil. Revista Brasileira de Epidemiologia, São Paulo, v. 8, n. 2, p. I27-I4 I, jun. 2005.

LING, C. H. Y. et al. Handgrip strength and mortality in the oldest old population: the Leiden 85-plus study. Canadian Medical Assocation Journal, Ottawa, v. I 82, n. 5, p. 429-435, mar. 2010.

LORD, S. R. et al. Sit-to-stand performance depends on sensation, speed, balance, and psychological status in addition to strength in older people. The journal of gerontology, serie a: biological sciences medical sciences, Oxford, v. 57, n. 8, p. M539-M543, aug. 2002.

LOUIE, G. H.; WARD, M. M. Association of measured physical performance and demographic and health characteristics with self-reported physical function: implications for the interpretation of self-reported limitations. Health and Quality of Life Outcomes, v. 8, p. 84, aug. 2010.

LOUVISON, M. C. et al. Inequalities in access to health care services and utilization for the elderly in São Paulo, Brazil. Revista de Saúde Pública, São Paulo, v. 42, n. 4, p. 733-740, aug. 2008.

O'CONNELL, H. et al. Alcohol use disorders in elderly people- redefining an age old problem in old age. British Medical Journal, London, v. 327, n. 74I6, p. 664-667, sept. 2003.

PIETERSE, S.; MANANDHAR, M.; ISMAIL, S. The association between nutritional status and handgrip strength in older Rwandan refugees. European Journal of Clinical Nutrition, London, v. 56, n. 10, p. 933-939, oct. 2002.

PROGRAMA DAS NAÇÕES UNIDAS PARA O DESENVOLVIMENTO. Atlas de desenvolvimento humano no Brasil. Brasília, 12 maio 2009. Disponível em: < http://www.pnud.org. br/atlas/textos_analiticos/index.php>. Acesso em: 12 maio 2009.

RAJI, M. A. et al. Cognitive status, muscle strength, and subsequent disability in older Mexican Americans. Journal of the American Geriatrics Society, Malden, v. 53, n. 9, p. I462- I468, sept. 2005. 
RIKLI, R. E.; JONES, C. J. Development and validation of a functional fitness test for community-residing older adults. Journal of Aging and Physical Activity, Champaign, v. 7, n. 2, p. |29-|6|, apr. 1999.

RONKSLEY, P. E. et al. Association of alcohol consumption with selected cardiovascular disease outcomes: a systematic review and meta-analysis. British Medical Journal, London, v. 342, p. d67I, feb. 201 I.

SAMPER-TERNENT, R. et al. Relationship between frailty and cognitive decline in older Mexican Americans. Journal of the American Geriatrics Society, Malden, v. 56, n. I0, p. 1845-1852, oct. 2008.

SOLFRIZZI, V. et al. Alcohol consumption, mild cognitive impairment, and progression to dementia. Neurology, Montreal Avenue St. Paul, v. 68, n. 21, p. 1790- 1799, may 2007.

TAEKEMA, D. G. et al. Handgrip strength as a predictor of functional, psychological and social health. A prospective population-based study among the oldest old. Age and Ageing, Oxford, v. 39, n. 3, p. 331-337, mar. 2010.

THOMAS, D. R. Loss of skeletal muscle mass in aging: examining the relationship of starvation, sarcopenia and cachexia. Clinical Nutrition, Edinburgh, v. 26, n. 4, p. 389-399, aug. 2007.

VALENTINE, R. J. et al. Sex impacts the relation between body composition and physical function in older adults. Menopause, New York, v. 16, n. 3, p. 518-23, may/jun. 2009.

Recebido em: 25 jan. 2012

Aprovado em: 28 dez. 2012

Endereço para correspondência:

Aline Rodrigues Barbosa

Departamento de Educação Física/

Centro de Desportos

Universidade Federal de Santa Catarina

Campus Trindade, $s / n$ Florianópolis-SC CEP: 88040-900 